\title{
A comparison of anthropogenic and elephant disturbance on Acacia xanthophloea (fever tree) populations in the Lowveld, South Africa
}

\section{J. Botha, E.T.F. WitKowSKI and C.M. SHACKLETON}

Botha, J., E.T.F. Witkowski and C.M. Shackleton. 2002. A comparison of anthropogenic and elephant disturbance on Acacia xanthophloea (fever tree) populations in the Lowveld, South Africa. Koedoe 45(1): 9-18. Pretoria. ISSN 0075-6458.

Acacia xanthophloea (the 'fever tree') is a popular medicinal species that is traded widely in South Africa. Although it occurs throughout southern Africa, there is increasing pressure on its riverine and marshy habitats. This study compares the impact of harvesting on an A. xanthophloea population located on private land near Komatipoort, Mpumalanga, with two protected populations situated within the Kruger National Park. The densities of the harvested and protected populations were similar $(84 \pm 8$ trees/ha and $85 \pm 20$ trees/ha, respectively). There were fluctuations in the quotients between frequencies of trees in successive diameter classes, which is common in savanna where high levels of fire, mega-herbivore and anthropogenic disturbance are experienced. The extent of stem damage (stripping of bark and breakage) by elephants in the protected area was significantly higher than the extent of harvesting on private land, although the degree of damage was relatively low, with only $7 \%$ of the populations having been damaged at rates $>26 \%$. The degree of harvesting on private land was relatively low, with the majority of trees having been harvested at rates of less than $10 \%$ of the stem below $2 \mathrm{~m}$. Despite this, ringbarking had occurred (4\%). The basal diameters and heights were significantly lower in the protected population than in the harvested one, suggesting that over time elephant impact was the more severe disturbance. Acacia xanthophloea exhibited high resilience to disturbance, with all the elephant damaged trees and harvested individuals surviving. However, the mean bark thickness measured in local markets $(6.3 \pm 1.4 \mathrm{~mm})$ was significantly lower than that measured in either the harvested $(12.4 \pm 1.0 \mathrm{~mm})$ or the KNP $(10.3 \pm 0.8 \mathrm{~mm})$ populations. As harvesters tend to select the largest individuals in a population to maximise their financial returns, this could mean that smaller individuals are being harvested, and/or bark is not being given sufficient time to grow back after harvesting. Acacia xanthophloea outside protected areas thus need to be monitored and the management improved, preferably in conjunction with the resource users. In addition, traditional healers, those selling medicinal plants and other members of the community need to continue to be encouraged to cultivate this fast growing species.

Key words: Acacia xanthophloea, disturbance, elephants, harvesting, medicinal plants, population dynamics.

J. Botha and E.T.F. Witkowski, Restoration and Conservation Biology Research Group, School of Animal, Plant and Environmental Sciences, University of the Witwatersrand, PO Wits, 2050 South Africa.; C.M. Shackleton, Environmental Science Programme, Rhodes University, Grahamstown, 6140, South Africa.

\section{Introduction}

Acacia xanthophloea Benth. (the 'fever tree') is widespread in the lowveld areas of KwaZulu-Natal, Mpumalanga and Northern Province, through to east Africa (Coates
Palgrave 1990). The Venda vernacular name, 'muunga gwena' (meaning 'predict the crocodile'), warns of potential inhabitants sharing the low lying, swampy or riverine habitats of this species. The Zulu and Swazi ver- 
nacular name (ukhanyakude) means 'shining from afar', and refers to the smooth, fluorescent green bark of the tree.

The tree is frequently a community dominant in swampy or riverine environments. The leaves, shoots and pods are browsed by domestic livestock and wild game. It is a favoured species of the African elephant Loxodonta africana, which may cause extensive damage to tree species with limited and localised populations (Cumming et al. 1997; Eckhardt et al. 2000), including A. xanthophloea (Van Wyk 1984).

The bark of $A$. xanthophloea is highly valued for its magico-medicinal properties, while the wood is a general-purpose timber. The bark is frequently traded, with material on sale in South African markets being harvested locally as well as imported from Mozambique (Botha 2001; Mander 1998). This species was ranked sixth out of the top 120 medicinal plant species utilised in the Bushbuckridge lowveld adjacent to the Kruger National Park (KNP) (Mander 1997), and eleventh out of the top 70 species in KwaZulu-Natal (Mander 1998). Despite the high demand for A. xanthophloea, and its restricted habitat within South Africa, $75 \%$ of respondents in Mpumalanga markets believed that it is still readily available (Botha 2001).

Disturbance by humans, mega-herbivores and other agents is common to a variety of natural systems and populations, and plays a vital role in determining species richness and the structure of plant and animal communities (Dublin et al. 1990; Moloney \& Levin 1996). However, the limits of disturbance that a population can withstand are usually unknown. With an estimated 20000 tons of medicinal plants being consumed in South Africa annually (Mander 1998), favoured species are now often vulnerable to overharvesting (Cunningham 1992; Mander 1998). This is often compounded by a decrease in the extent of habitats as human needs escalate. The remaining populations of popular species are thus, in all likelihood, experiencing an increase in the magnitude and frequency of disturbance. Similarly, the effects of mega-herbivores are concentrated in ever-decreasing areas, often to the detriment of woody plant populations and biodiversity within protected areas (Cumming et al. 1997).

There are a number of ways to determine the impacts of natural, human and megaherbivore induced disturbances on woody plant populations. Repeated measures in long-term monitoring plots are perhaps the most desirable due to the high longevity of many tree species. However, this may take many years or decades, and hence is costly relative to the final outputs. Consequently, snapshot surveys are frequently employed as the primary approach to determine whether further in-depth monitoring is required. Despite the limitations of these surveys, they can provide useful data that is readily available to management. Interpretation of sizeclass profiles have been shown to be useful in assessing the state of populations for a variety of management purposes (Shackleton et al. 1994; Taylor \& Walker 1984; Witkowski et al. 1994), as changes in the structure of a population often occur before changes in species composition (Harper 1977; Shackleton 1993). The characterisation of size class distributions is also a useful means of projecting population trends, and to a lesser extent, past trends (Harper 1977). Although limited information is available on the extent of harvesting of certain medicinal species (Cunningham 1992; La Cock \& Briers 1992), little is known of the impact of harvesting on the population structure of key species. Within this context, this paper presents data that permit a comparative evaluation of the impacts of mega-herbivores within a protected area (the KNP) and human harvesting outside the protected area on localised populations of A. xanthophloea, as part of the larger survey of Botha (2001).

\section{Study area}

The harvested population was assessed whilst accompanying medicinal plant vendors on a harvesting trip, and was located on 
private land near Komatipoort $\left(25^{\circ} 25^{\prime} \mathrm{S}\right.$; $\left.31^{\circ} 55^{\prime} \mathrm{E}\right)$. The two protected populations were located within the KNP near Crocodile Bridge, which is situated approximately $13 \mathrm{~km}$ from Komatipoort. The harvested population is classified as Lowveld veld type 10 (Acocks 1988) and the KNP populations as Landscape 17, Sclerocarya birrea and Acacia nigrescens savanna (Gertenbach 1983).

Within the Mpumalanga lowveld, rainfall occurs mainly in summer, from October to May. The mean annual rainfall of Komatipoort between 1903 and 1995 was $562 \pm 4 \mathrm{~mm}$ (South African Weather Bureau 2001). The mean maximum temperature in January between 1993 and 2001 was $32.0 \pm$ $1.1{ }^{\circ} \mathrm{C}$, while that in July was $26.0 \pm 0.3{ }^{\circ} \mathrm{C}$. The mean minimum temperature for January was $21.3 \pm 0.8^{\circ} \mathrm{C}$, and that for July was 10.0 $\pm 0.5^{\circ} \mathrm{C}$. Frost seldom occurs.

\section{Methods}

The basal diameters and heights of all the A. xanthophloea stems were measured and assessed in two plots $(40 \mathrm{~m} \times 100 \mathrm{~m})$ in the harvested population and one plot $(40 \mathrm{~m} \times 100 \mathrm{~m})$ in each of two different populations in the KNP. In this study, the 'extent' of disturbance refers to the proportion of a population affected and the 'degree' to the severity of damage. The external damage to the stem was evaluated on a scale adapted from Cunningham's seven-point scale for stem damage (Cunningham 1992) (Fig. 1). The cause of damage was noted, for example, harvesting or natural causes (fire, herbivory, elephant damage), as well as the state of health of the stem (alive, dead, appearance of physiological stress). Stems classified as dead were desiccated or rotten, with no shoots or other signs of life. Stems classed as stressed showed signs of disease (rotting stems or branches) and/or desiccation, but part of the plant was still alive, or it was coppicing. Signs of harvesting and elephant damage are distinctive, the former because bark is usually neatly cut off the stem. Elephants break branches, strip bark and, occasionally, push over trees. Kudus usually browse branches at levels of up to $2.5 \mathrm{~m}$ (N. Owen-Smith pers. comm.).

The bark thickness measured in the harvested and protected populations was compared with that of the bark on offer in the medicinal plant markets in the region. A small piece of bark was cut from the stem at a height of approximately $1.5 \mathrm{~m}$, and its thickness measured. As harvesters tend to target the largest individuals in a population to maximise their returns, the bark thickness measured in the size classes of the population that were currently being harvested was utilised in data analysis rather than the mean, as the size of the mean is influenced by the number of seedlings and smaller individuals in a population.

Stems with basal diameters of $<1 \mathrm{~cm}$ were regarded as newly derived stems, and are termed recruits. Apart from size classes $1(0-1 \mathrm{~cm})$ and $2(2-5 \mathrm{~cm})$, size classes were grouped into basal diameters of 5 $\mathrm{cm}$ increments. Size classes 3 and upwards consisted of stems of 6-10 cm, $11-15 \mathrm{~cm}, 16-20 \mathrm{~cm}$, etc. The
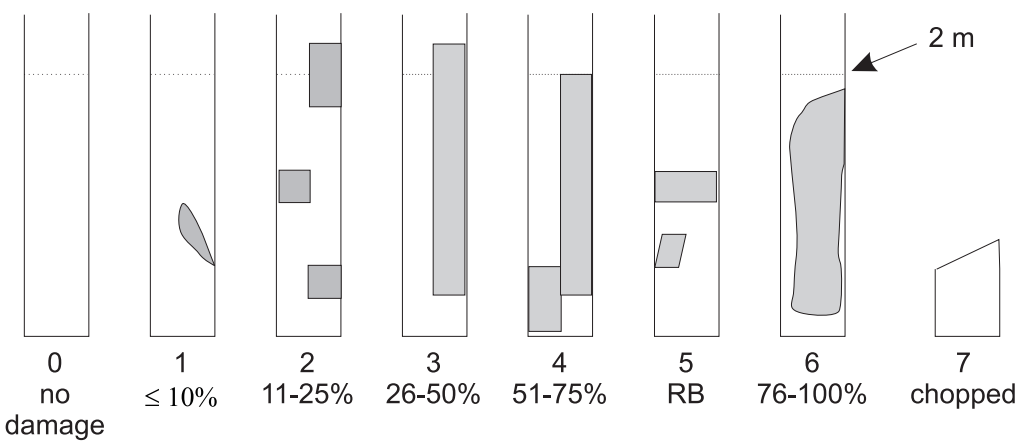

$$
\mathrm{RB}=\text { ring barked, any } \%
$$

Fig. 1. Eight point scale used in the assessment of bark damage on a tree trunk. All assessments represent the proportion of bark removed below $2 \mathrm{~m}$, indicated by the dotted line (adapted from Cunningham 1992). 
relative frequencies in each size class were displayed graphically. Densities were also determined.

Statistical analyses were performed using Systat 7.0 (1997) and Excel 2000. Size class distributions of harvested and protected populations were compared by means of Kolmogorov-Smirnov tests. Histograms were used to display the degree of harvesting in populations. The percentages of trees of harvestable size were calculated according to the size classes of populations that were currently being harvested. Chi squared $\left(\chi^{2}\right)$ analyses were used to compare the proportions of trees of harvestable sizes in the harvested and protected populations, as well as the proportions of individuals that had survived after harvesting or other disturbance. Smaller size classes were pooled to ensure a minimum number of five in each class. Non-parametric statistics were used to compare basal diameter and height variations between the harvested and protected populations (Kruskal Wallis and Mann Whitney $U$-tests). A One Way Anova was used to compare bark thickness.

Quotients, which provide a measure of the stability of a population (Harper 1977; Meyer 1952), were calculated and displayed graphically. In a stable population, the quotient between the numbers of trees in successive diameter classes approaches a constant value. Fluctuating quotients indicate an unstable population.

Population structure can also be described using a combination of Simpson's Index of Dominance (C) and the Permutation Index (P) (Wiegand et al. 2000). Simpson's Index of Dominance describes the probability that any two trees drawn at random from the same community are of the same species or, in this case, from the same size class, by measuring the occurrence of dominant (more frequent) size classes (Pielou 1977; Wiegand et al. 2000) (equation 1). In the latter application, the Simpson Index measures the evenness of occupation of size classes, ignoring the order in which the size classes are arranged (Wiegand et al. 2000). Values above 0.1 reveal that the size frequency is steeper than would be expected from an exponentially declining population (i.e. the columns are arranged in descending order), while values below 0.1 show that the size classes are more evenly distributed.

$$
\mathrm{C}=1 / \mathrm{N}(\mathrm{N}-1) \sum_{i=1}^{20} \mathrm{~N}_{i}(\mathrm{~N}-1)
$$

equation 1

where C is Simpson's Index of Dominance, $\mathrm{N}$ is the total number of trees and $\mathrm{N}_{i}$ is the number of trees in class $i$.
The Permutation Index measures deviation from a monotonic decline (equation 2), which would be expected in an "ideal" population (Wiegand et al. 2000). The absolute distances between the expected and real location (rank) of all the size classes are summed, ignoring the relative frequencies of the different size classes. If a size distribution is discontinuous, with larger individuals in preceding size classes, the Permutation Index is higher than that of a continuous monotonically declining population.

$$
\mathrm{P}=\sum_{i=1}^{20}\left|J_{i}-i\right| J_{i}=1,2, \ldots, 20 \quad \text { equation } 2
$$

where $\mathrm{P}$ is the Permutation Index, $J_{i}$ is the rank of size class $i(i=1$ for the smallest trees), with the highest rank $\left(J_{i}=1\right)$ given to the most frequent size class.

\section{Results}

\section{Population parameters}

The densities of $A$. xanthophloea were similar in the harvested ( $84 \pm 9$ trees/ha) and protected plots $(85 \pm 20$ trees/ha). The total population size at the harvested site was approximately 300 while those in the KNP were approximately $66 \pm 19$ (Table 1).

Kolmogorov-Smirnov tests showed a significant difference between the distribution of the basal diameters of the harvested population and the protected populations $\left(D_{68,68}=0.31 ; p<0.005\right)$ (Fig. 2a). The basal diameters of the latter populations were significantly lower than those of the harvested population $(12.3 \pm 1 \mathrm{~cm}$ and $22.5 \pm 2.7 \mathrm{~cm}$, respectively) $\left(U_{68,68}=3192.00 ; p<0.005\right)$, as were the heights $(3.2 \pm 0.2 \mathrm{~m}$ and $9.7 \pm 0.8 \mathrm{~m}$, respectively) $\left(U_{68,68}=3231.00 ; p<0.005\right)$ (Table 2).

The density of recruits was low in all plots $(4 \pm 2$ trees/ha in the harvested and $22 \pm$ 20 trees/ha in the protected populations). The proportions of recruits in the harvested and protected populations were similar (4\% and $6 \%$, respectively). Only two trees had coppiced in the harvested population, and three in the Kruger National Park. 
Table 1

Population parameters of harvested and protected Acacia xanthophloea populations. Values with different superscript letters are significantly different (Mann Whitney U-Test $* * \mathrm{p}<0.005$ )

\begin{tabular}{lccc}
\hline & $\begin{array}{c}\text { Harvested } \\
\text { (Komatipoort) }\end{array}$ & $\begin{array}{c}\text { Protected area } \\
(\mathrm{KNP})\end{array}$ & $p$ Value \\
\hline Estimated population size & 300 & $69 \pm 22(47-90)$ & \\
Population density $(\overline{\mathrm{X}} \pm \mathrm{SE}$ (range) (trees/ha) & $84 \pm 8(76-92)$ & $85 \pm 20(65-105)$ & \\
Recruit density $(\overline{\mathrm{X}} \pm(\mathrm{SE}$ (range) $(\mathrm{recruits} / \mathrm{ha})$ & $4 \pm 2(2-6)$ & $22 \pm 20(2-42)$ & $* *$ \\
Basal diameter $(\overline{\mathrm{X}} \pm \mathrm{SE}($ range) $(\mathrm{cm})$ & $22.5 \pm 2.7^{\mathrm{a}}(0.3-121)$ & $12.3 \pm 1.2^{\mathrm{b}}(0.2-35)$ & $* *$ \\
Height $(\overline{\mathrm{X}} \pm \mathrm{SE}($ range $)(\mathrm{m})$ & $9.7 \pm 0.8^{\mathrm{a}}(1.2-21)$ & $3.2 \pm 0.2^{\mathrm{b}}(0.7-9)$ & $* *$ \\
Simpson's Index of Dominance $(\mathrm{C})$ & 0.09 & 0.15 & \\
Permutation Index $(\mathrm{P})$ & 22 & 8 & \\
\hline
\end{tabular}

The quotients fluctuated in both the harvestly distributed in the harvested $(\mathrm{C}=0.09)$ ed and the protected populations (Fig. 2b). The size class frequencies were discontinuous in both populations but were more eventhan in the protected population $(\mathrm{C}=0.15)$. The higher Permutation Index of the harvested population $(\mathrm{P}=22)$ indicates that the

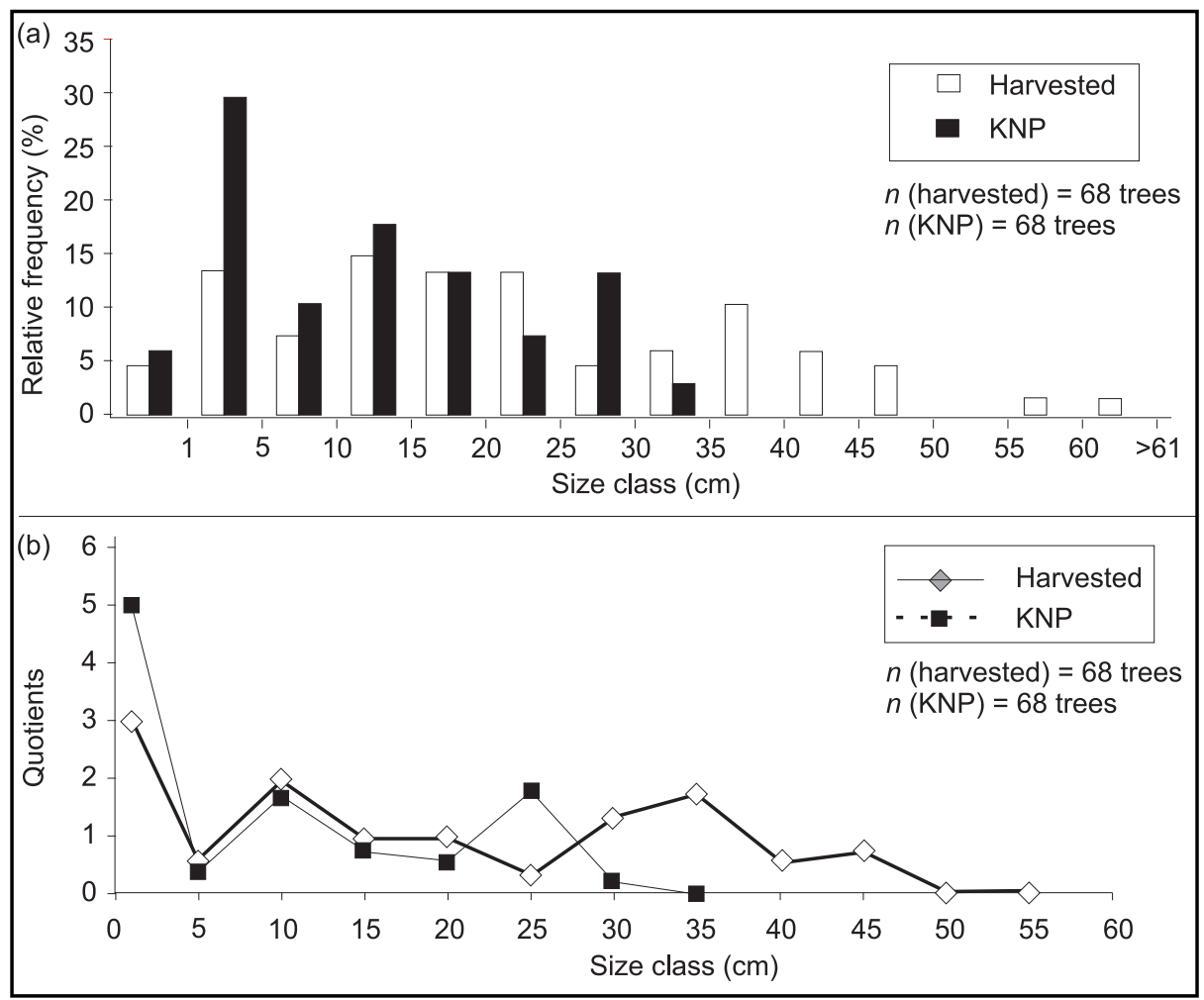

Fig. 2. Population structures of harvested and protected Acacia xanthophloea populations: (a) relative frequencies and (b) quotients between numbers of trees in successive size classes. Size classes are based on basal diameters. 
level of discontinuity was higher than in the KNP populations $(\mathrm{P}=8)$.

\section{Harvesting}

There was no significant difference between the proportions of $A$. xanthophloea of harvestable size in the harvested and the protected populations $\left(\chi^{2}=1.471 ;\right.$ d.f. $=1$; $p>0.05$ ). No A. xanthophloea had been harvested on the KNP sites. However, the extent of stem damage (stripping of bark and breakage) by elephants in the protected area was significantly higher than the extent of harvesting on private land $\left(\chi^{2}=8.71 ;\right.$ d.f. $=1$; $p<0.005$ ) (Table 2) affecting all but the lowest size class (Fig. 3a). The degree of harvesting on private land was low and mainly occurred from size class $5(16-20 \mathrm{~cm})$ onwards. The majority of trees had been harvested at rates of less than $10 \%$ of the stem below $2 \mathrm{~m}$. Despite this, ringbarking had recently occurred $(4 \%)$. The ringbarking was too recent to ascertain whether ringbarked individuals would survive. The degree of damage to stems by elephants in the protected area was also relatively low, with only $7 \%$ of the populations having been damaged at rates $>26 \%$.

\section{Bark thickness}

There was a significant difference between the maximum bark thickness of $A$. xanthophloea measured in the field, and the bark on offer to consumers in the market place (One-Way ANOVA $F_{2,42}=6.91 ; p<0.005$ ).
The bark thickness measured in the markets $(6.3 \pm 1.4 \mathrm{~mm})$ was significantly lower than the thickness of bark measured in the harvested $(12.4 \pm 1.0 \mathrm{~mm}) \quad$ (Bonferroni $p<0.005)$ and the KNP populations $(10.3 \pm 0.8 \mathrm{~mm})$ (Bonferroni $p<0.05)$. There was no significant difference between the thickness of bark of the harvested and protected area populations (Bonferroni $p>0.05)$.

\section{Discussion}

Population structure and vigour are affected by a variety of factors (Schemske et al. 1994). This study provides a snapshot of the assessed populations at a single point. The effects of human harvesting of woody species in communal areas are often manifest as a decrease in the number of larger individuals in a population due to selective harvesting (Rao et al. 1990; Shackleton 1993). In contrast, patterns of damage due to mega-herbivores are more random in distribution, extent, and size-classes affected. Any damage to a mature stem may inhibit future growth of an individual due to physiological stress, and the opening of wounds susceptible to infection. The protected A. xanthophloea populations in KNP had significantly lower basal diameters and heights relative to the harvested population outside the national park. This suggests that the impact of elephant damage in the former populations was more severe than the impact of human harvesting in the latter. This high

Table 2

Extent of harvesting of Acacia xanthophloea populations, and fate of harvested stems

\begin{tabular}{|c|c|c|c|c|c|}
\hline & \multirow{2}{*}{$\begin{array}{c}\text { Proportion of } \\
\text { stems of } \\
\text { harvestable size } \\
\bar{X} \pm \text { SE } \\
\text { (Range) \% }\end{array}$} & \multirow{2}{*}{$\begin{array}{c}\text { Proportion of } \\
\text { stems harvested } \\
\text { or damaged } \\
\text { by elephants } \\
\overline{\mathrm{X}} \pm \mathrm{SE} \\
\text { (Range) } \%\end{array}$} & \multicolumn{3}{|c|}{$\begin{array}{l}\text { Fate }(\%) \text { of harvested trees, or } \\
\text { trees damaged by elephants }\end{array}$} \\
\hline & & & Dead & Alive & Stressed \\
\hline $\begin{array}{l}\text { Harvested } \\
\text { (Komatipoort) }\end{array}$ & $\begin{array}{l}83.5 \pm 2.5 \\
(81-86)\end{array}$ & $\begin{array}{l}23.0 \pm 4.0 \\
(19-27)\end{array}$ & 0 & 100 & 0 \\
\hline $\begin{array}{l}\text { Protected } \\
\text { (KNP) }\end{array}$ & $\begin{array}{c}72.0 \pm 20.0 \\
(52.0-92.0)\end{array}$ & $\begin{array}{l}49.5 \pm 25.5 \\
(24-75)\end{array}$ & 0 & 100 & 0 \\
\hline
\end{tabular}



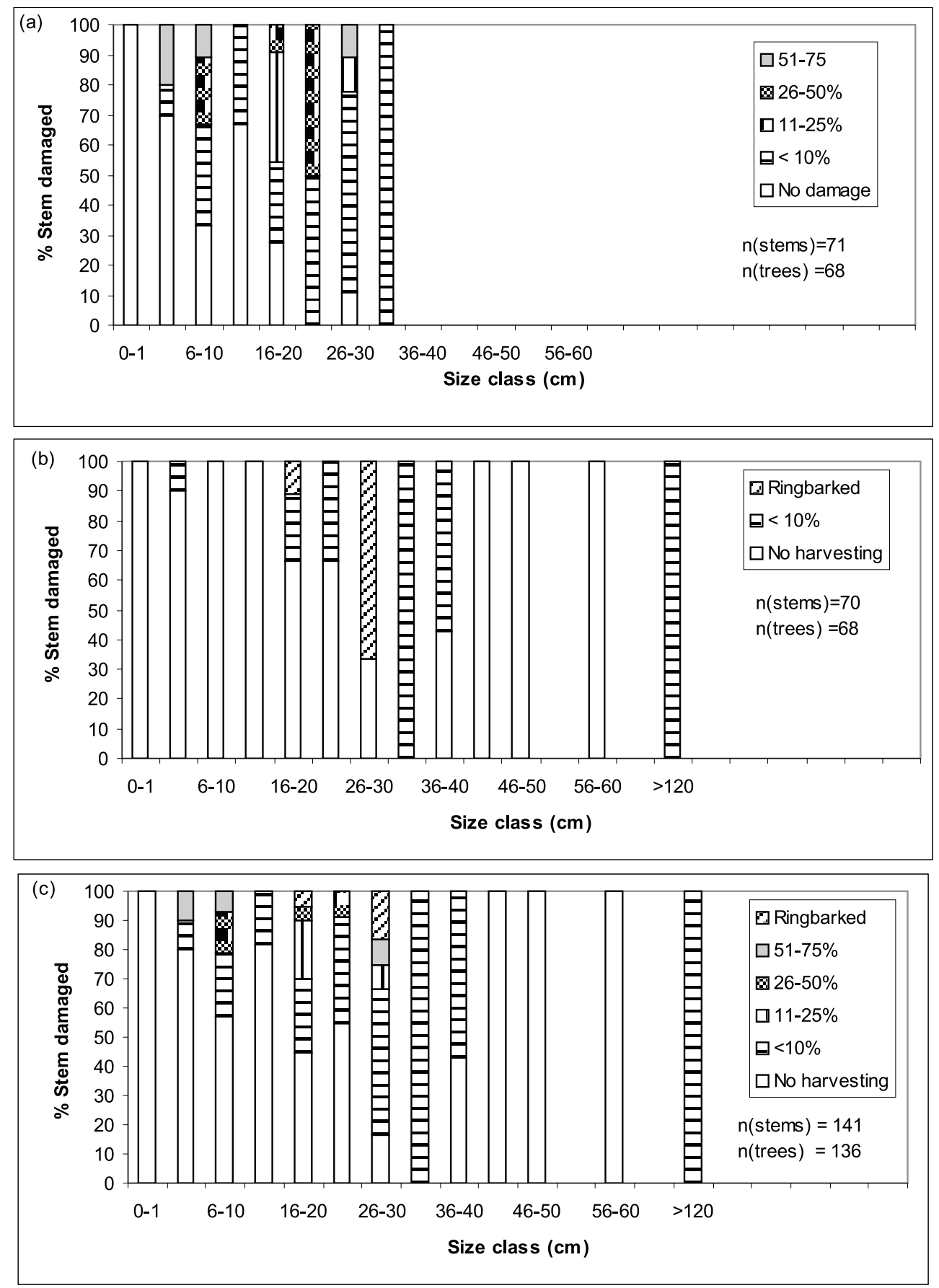

Fig. 3. Degree of stem damage to Acacia xanthophloea through bark removal below $2 \mathrm{~m}$, and breakage or chopping (a) through elephants in protected area sites (stripping of bark and breakage of stems) and (b) harvesting on private land. (c) Pooled populations. Size classes based on basal diameters. 
impact of elephant damage is not an unusual finding. For example, between 1996 and 1998 there was a $73 \%$ increase in tree damage on the Kingston property in the Sabie Sands Game Reserve (which abuts the KNP), corresponding to the migrant elephant population more than doubling from $1 / 1045$ ha in 1993 to $1 / 306$ ha in 1996 (although the current elephant population is believed to be sustainable) (Hiscocks 1999). In the Welgevonden Nature Reserve (30 000 ha), located in the Waterberg mountains in Northern Province, species such as Aloe marlothii Berger, Pappea capensis Ecklon \& Zeyher and Elephantorrhiza burkei Benth. have been so severely impacted by elephants that they are likely to become extinct within 10 years of the elephants being introduced to the reserve (A. Parker, unpublished data). The compatibility of attempting to simultaneously maximise biodiversity conservation in general with large elephant populations has thus been questioned (Cumming et al. 1997). However, the role of disturbance (whether by elephants or humans) in optimising species richness also needs greater investigation in light of recent work indicating higher species richness of plants and small mammals outside protected areas than inside (Caro 2001; Shackleton 2000a).

Increased disturbance, whether by humans or mega-herbivores, may impact tree recruitment negatively or positively, depending on the species and the severity of disturbance (Rao et al. 1990; Shackleton et al. 1994). The density of recruits was low in both populations, but this may be a reflection of regeneration being periodic rather than continuous, a common attribute of many Acacia species (Prins \& Van der Jeugd 1993; Wiegand et al. 2000; Witkowski \& Garner 2000). Acacia xanthophloea regeneration has also been found to be limited by water stress in dry conditions (Otieno et al. 2001) and by high proportions of non-viable seeds, which are prone to rotting and heavy parasitisation in their pods (Carr 1976).

Fluctuating quotients are common attributes of savanna tree population profiles, due to the absence of continuous recruitment and frequent disturbance through fire, herbivory, human impacts and climatic variations (Shackleton 1993). The irregular size class distributions found in many Acacia species have been ascribed to episodic recruitment and irregular growth patterns (Prins \& Van der Jeugd 1993; Wigand et al. 2000). The size class frequency of the KNP population was steeper than would be expected from a monotonic decline but the size classes of the harvested A. xanthophloea population were relatively evenly distributed. A monotonic decline (and thus a higher Simpson's Index) would be anticipated in heavily harvested populations, where there are often high recruit frequencies with low frequencies in the larger size classes targeted by harvesters. For example, harvested populations of Warburgia salutaris, Catha edulis and Rapanea melanophloeos exhibited a higher level of monotonic decline than unharvested populations (Botha 2001). The lower Simpson's Index occurring in the harvested $A$. xanthophloea population may be partially due to the relatively low degree of disturbance and partially due to the regeneration and growth patterns of the species. Further research would be required to test this hypothesis.

The extent of damage caused by elephants in the protected population was higher than the extent of harvesting on the population growing on private land, although the degree of damage was relatively low in all populations. All damaged trees, whether by humans or elephants, had survived. Acacia xanthophloea also displayed a high level of tolerance to substantial debarking and branch removal by elephants in Amboseli (Young \& Lindsay 1988). Most savanna tree species are capable of regrowth even when the whole stem is removed or cut (Shackleton 2000b).

Given the current degree of damage in both the harvested and elephant damaged populations, and the tolerance of $A$. xanthophloea to damage, there appears to be little cause for concern regarding possible localised extinction of the assessed populations at the current levels of disturbance. Additional popu- 
lations should be assessed to determine whether this applies to a wider range of sites. However, the demand for 'ukhanyakude' is high (Botha 2001; Mander 1997, 1998) and is not going to diminish in the foreseeable future. Substantial quantities of bark of this species are already being imported into South Africa from neighbouring countries (Botha 2001; Mander 1998). The thickness of bark being traded in markets in Mpumalanga was significantly lower than that of populations measured in the field, indicating that the individuals being harvested may be considerably smaller than the assessed populations, or that bark re-growth is being harvested before it has had sufficient time to grow back. This, in conjunction with the effects of shrinking habitats on local plant populations, means that plant conservation needs to become a higher priority both within and outside protected areas. Within reserves, the main management focus has historically been on charismatic animal species. While this has shifted to the conservation of ecosystems or landscapes, with increasing emphasis on biodiversity (Braack 1997; Simberloff 1998), diminishing financial and human resources are adversely affecting the management of many protected areas in South Africa (Pfab \& Witkowski 1999). Pressure to improve the financial viability of reserves through tourism is also mounting, often resulting in species such as elephant being introduced into smaller reserves, or increasing their numbers to improve sighting opportunities, sometimes at the expense of plant communities (e.g. Moolman \& Cowling 1994). Acacia xanthophloea also requires improved management outside protected areas, both by improving the management and monitoring of harvested populations and through higher levels of cultivation. Co-operative programmes need to be implemented across geographic and sectoral boundaries, including conservationists, traditional healers, medicinal plant vendors and traders, the private sector (e.g. forestry and pharmaceutical companies, and medicinal plant enterprises) and the public sector (e.g forestry and agriculture). It is only through a proactive, co- ordinated and sustained effort that the longterm survival of valued species such as $A$. xanthophloea will be assured.

\section{Acknowledgements}

This project formed one component of The Green Trust funded Kruger National Park Traditional Healers Programme. Logistical support was provided by South African National Parks and the University of the Witwatersrand. Nick Zambatis, Flip Nel and Johan van Graan are thanked for assistance in organising the KNP fieldwork. Michael Mabunda and Zodwa Mashele provided invaluable assistance in the field. Dr Hugo Bezuidenhout and two anonymous reviewers are thanked for their constructive comments on this paper.

\section{References}

Acocks, J.P.H. 1988. Veld Types of South Africa. 3rd edn. Memoirs of the Botanical Survey of South Africa 57: 1-146.

Bотна, J. 2001. Perceptions of availability and values of medicinal plants traded in areas adjacent to the Kruger National Park. M.Sc. dissertation, University of the Witwatersrand, Johannesburg.

BrAACK, L. 1997. A revision of parts of the management plan for the Kruger National Park. Volume VIII: Policy proposals regarding issues relating to biodiversity maintenance, maintenance of wilderness qualities, and provision of human benefits. Unpublished report, South African National Parks, Skukuza.

CARO, T.M. 2001. Species richness and abundance of small mammals inside and outside an African national park. Biological Conservation 98: 251-257.

CARR, J.D. 1976. The South African Acacias. Johannesburg: Conservation Press (Pty) Ltd.

Coates Palgrave, K. 1990. Trees of southern Africa. Cape Town: Struik Publishers.

Cumming, D.H.M., M.B. Fenton, I.L. Rautenbach, R.D. Taylor, G.S. Cumming, M.S. Cumming, J.M. Dunlop, A.G. Ford, M.D. HovorKa, D.S. Johnston, M. Kalcounis, Z. MahlamGu \& C.V. PorTFOS. 1997. Elephants, woodlands and biodiversity in southern Africa. South African Journal of Science 93: 231-236.

Cunningham, A.B. 1992. Imithi isiZulu: the traditional medicine trade in Natal/KwaZulu. Master of Social Science dissertation, University of Natal, Pietermaritzburg.

Dublin, H.T., A.R. Sinclair \& J. McGlade. 1990. Elephants and fire as causes of multiple stable 
states in the Serengeti-Mara woodlands. Journal of Animal Ecology 59: 1147-1164.

ECKHARDT, H.C., B.W. VAN WILGEN \& H.C. BigGS. 2000. Trends in woody vegetation cover in the Kruger National Park, South Africa, between 1940 and 1998. African Journal of Ecology 38: 108-115.

GertenBaCH, W.P.D. 1983. Landscapes of the Kruger National Park. Koedoe 26: 9-121.

HARPER, J.L. 1977. Population biology of plants. San Diego: Academic Press.

HISCOCKS, K. 1999. The impact of an increasing elephant population on the woody vegetation in southern Sabi Sand Wildtuin, South Africa. Koedoe 42(2): 47-55.

LA Cock, G.D. \& J.H. Briers. 1992. Bark collecting at Tootabie Nature Reserve, eastern Cape, South Africa. South African Journal of Botany 58: 505-509.

MANDER, M. 1997. Medicinal plant marketing and strategies for sustaining the plant supply in the Bushbuckridge area and Mpumalanga Province. Nelspruit: Unpublished report, Department of Water Affairs and Forestry. (DWAF/DANCED).

MANDER, M. 1998. Marketing of indigenous medicinal plants in South Africa. A case study in Kwazulu-Natal. Rome: Food and Agricultural Organisation of the United Nations.

Meyer, H.A. 1952. Structure, growth and drain in balanced uneven-aged forests. South African Journal of Botany 52: 387-402.

Moloney, K.A. \& S.A. LeVIn. 1996. The effects of disturbance architecture on landscape-level population dynamics. Ecology 77: 375-394.

Moolman, H.J. \& R.M. Cowling. 1994. The impact of elephant and goat grazing on the endemic flora of South African succulent thicket. Biological Conservation 68: 53-61.

Otieno, D.O., J.I. KinYamario \& T.O. OMEnda. 2001. Growth features of Acacia tortilis and Acacia xanthophloea seedlings and their response to cyclic soil drought stress. African Journal of Ecology 39: 126-132.

PFAB, M.F. \& E.T.F. WitKowsKi. 1999. Contrasting effects of herbivory on plant size and reproductive performance in two populations of the Critically Endangered species, Euphorbia clivicola R.A. Dyer. Plant Ecology 145: 317-325.

Pielou, E.C. 1977. Mathematical Ecology. New York: John Wiley.

Prins, H.H. \& H.P. van DER JeUgD. 1993. Herbivore population crashes and woodland structure in East Africa. Journal of Ecology 81: 305-314.

RaO, P., S.K. Barik, H.N. Pandey \& R.S. TRipathi. 1990. Community composition and tree popula- tion structure in a sub-tropical broad-leaved forest along a disturbance gradient. Vegetatio 88: 151-162.

Schemske, D.W., B.C. Husband, M.H. Ruckelshaus, C. Goodwill, I.M. Parker \& J.G. BisHOP. 1994. Evaluating approaches to the conservation of rare and endangered plants. Ecology 75: 584-606.

ShaCKLETON, C.M. 1993. Demography and dynamics of the dominant woody species in a communal and protected area of the eastern Transvaal Lowveld. South African Journal of Botany 59: 569-574.

ShaCKLeton, C.M. 2000a. Comparison of plant diversity in protected and communal lands in the Bushbuckridge lowveld savanna, South Africa. Biological Conservation 94: 273-285.

Shackleton, C.M. 2000b. Stump size and the number of coppice shoots for selected savanna tree species. South African Journal of Botany 66: 124-127.

Shackleton, C.M., N.J. Griffin, D.I. BanKs, J.M. MAVRANDONIS \& S.E. SHACKLETON. 1994. Community structure and species composition along a disturbance gradient in a communally managed South African savannah. Vegetatio 115: 157-167.

SimberLofF, D. 1998. Flagships, umbrellas, and keystones: is single-species management passé in the landscape era? Biological Conservation 83: 247-257.

TAYLOR S.E. \& B.H. WALKER. 1984. Autecology of an invading population of the cactus Cereus peruvianus (Queen of the night) in the central Transvaal. South African Journal of Botany 3: 387-396.

VAN WyK, P. 1984. Trees of the Kuger National Park. Cape Town: Struik Publishers.

Wiegand, K., D. Ward, H.H. Thulke \& F. Jeltsch. 2000. From snapshot information to long-term population dynamics of Acacias by a simulation model. Plant Ecology 150: 97-114.

WitKowski, E.T.F. \& R.D. GARnER. 2000. Spatial distribution of soil seed banks of three African savanna woody species at two contrasting sites. Plant Ecology 149: 91-106.

Witkowski E.T.F., B.B. LAMONT \& F.J. OBbens. 1994. Commercial picking of Banksia hookeriana in the wild reduces subsequent shoot, flower and seed production. Journal of Applied Ecology 31: 508-520.

YounG, T.P. \& W.K. LindSAY. 1988. Role of evenage populations in the disappearance of Acacia xanthophloea woodlands. African Journal of Ecology 26: 69-71. 